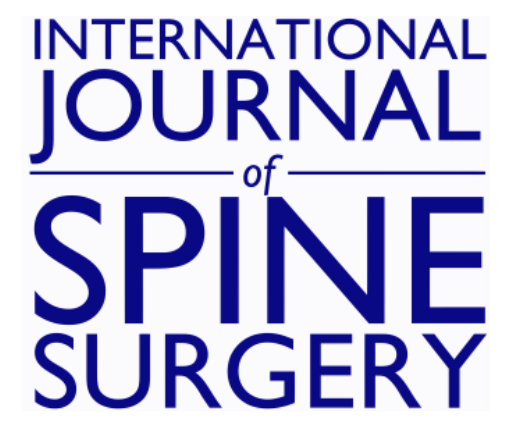

\title{
Radiographic Comparison of Lateral Lumbar Interbody Fusion Versus Traditional Fusion Approaches: Analysis of Sagittal Contour Change
}

Jonathan N. Sembrano, Sharon C. Yson, Ryan D. Horazdovsky, Edward Rainier G. Santos and David W. Polly, Jr.

Int J Spine Surg 2015, 9 ()

doi: https://doi.org/10.14444/2016

http://ijssurgery.com/content/9/16

This information is current as of April 26, 2023.

Email Alerts Receive free email-alerts when new articles cite this article. Sign up at:

http://ijssurgery.com/alerts

The International Journal of Sphine Surgerbittp://ijssurgery.com/ by guest on April 26, 2 2397 Waterbury Circle, Suite 1,

Aurora, IL 60504, Phone: +1-630-375-1432

(C) 2015 ISASS. All Rights Reserved. 


\section{Radiographic Comparison of Lateral Lumbar Interbody Fusion Versus Traditional Fusion Approaches: Analysis of Sagittal Contour Change}

Jonathan N. Sembrano, MD, Sharon C. Yson, MD, Ryan D. Horazdovsky, MD, Edward Rainier G. Santos, MD, David W. Polly Jr., MD Department of Orthopaedic Surgery, University of Minnesota, Minneapolis, $M N$

\section{Abstract}

\section{Background}

Lateral approach to lumbar fusion has been gaining popularity in recent years. With increasing awareness of the significance of sagittal balance restoration in spinal surgery, it is important to investigate the potential of this relatively new approach in correcting sagittal deformities in comparison to conventional approaches. The aim of this study was to evaluate sagittal contour changes seen in lateral lumbar interbody fusion and compare them with radiographic changes in traditional approaches to lumbar fusion.

\section{Methods}

Lumbar fusion procedures from January 2008 to December 2009 were reviewed. Four approaches were compared: anterior lumbar interbody fusion (ALIF), lateral lumbar interbody fusion (LLIF), transforaminal interbody fusion (TLIF) and posterior spinal fusion (PSF). Standing pre-operative and 6-week post-operative radiographs were measured in terms of operative level, suprajacent and subjacent level, and regional lumbar lordosis (L1-S1) as well as operative level anterior (ADH) and posterior disc heights (PDH). T-test was used to analyze differences between and within different approaches $(\alpha=0.05)$.

\section{Results}

A total of 147 patients underwent lumbar fusion at 212 levels. Mean operative level segmental lordosis change after each procedure is as follows: ALIF $3.8 \pm 6.6^{\circ}(\mathrm{p}<0.01)$; LLIF $3.2 \pm 3.6^{\circ}(\mathrm{p}<0.01)$; TLIF $1.9 \pm 3.9^{\circ}(\mathrm{p}<0.01)$; and PSF $0.7 \pm 2.9^{\circ}(\mathrm{p}=0.13)$. Overall lumbar lordosis change after each procedure is as follows: ALIF $4.2 \pm 5.8^{\circ}(\mathrm{p}<$ $0.01)$; LLIF $2.5 \pm 4.1^{\circ}(\mathrm{p}<0.01) ;$ TLIF $2.1 \pm 6.0(\mathrm{p}=0.02)$; PSF $-0.5 \pm 6.2^{\circ}(\mathrm{p}=0.66)$. There were no significant changes in the supradjcent and subjacent level lordosis in all approaches except in ALIF where a significant decrease in supradjecent level lordosis was seen. Mean ADH and PDH significantly increased for all approaches except in PSF where PDH decreased post-operatively.

\section{Conclusion}

LLIF has the ability to improve sagittal contour as well as other interbody approaches and is superior to posterioronly approach in disc height restoration. However, ALIF provides the greatest amount of segmental and overall lumbar lordosis correction.

\section{Level of Evidence}

This is a Level III study.

\section{Clinical Relevance}

Regional lordosis correction may be effectively achieved with LLIF. This approach is a good addition to a surgeon's armamentarium in maintenance or restoration of normal lumbar sagittal alignment. 


\section{Introduction}

The importance of sagittal plane correction in spinal fusion surgery is well-recognized. Preservation or restoration of sagittal balance has been shown to be the most important predictor of patient outcome in spine surgery. ${ }^{1}$ Forward displacement of the $\mathrm{C} 7$ plumbline or sagittal vertical axis (SVA), a condition referred to as positive sagittal imbalance, leads to chronic back pain secondary to increased intradiscal pressures and to paraspinal muscle fatigue in an effort to keep the body from falling forward.$^{2-4}$ Studies have shown that fusing the lumbar spine in kyphosis predisposes to development of adjacent segment disease (ASD) $)^{5-7}$

Lateral lumbar interbody fusion (LLIF), also referred to as XLIF (Extreme Lateral Interbody Fusion) or DLIF (Direct Lateral Interbody Fusion), is a minimally-invasive lateral retroperitoneal transpsoas approach to facilitate access to the lumbar disc space for interbody fusion. First described in 2006, it has subsequently continued to gain popularity. ${ }^{8}$ Potential advantages of this approach include minimizing the risk of complications associated with either the anterior approach (e.g. prolonged ileus, retrograde ejaculation, deep venous thrombosis and vascular injuries) or the posterior approach (e.g. paraspinal muscle injury and weakness, dural tear and nerve injury from excessive retraction). ${ }^{9-11}$

There have been few comparative studies between anterior lumbar interbody fusion (ALIF) and transforaminal lumbar interbody fusion (TLIF), ${ }^{12,13}$ as well as case series looking at radiographic changes after LLIF. ${ }^{14-17}$ To date, there has only been one published study directly comparing radiographic changes between LLIF and other commonly performed interbody fusion approaches (ALIF and TLIF).$^{18,19}$ However, there has not been any study on LLIF that included a negative control group, where no interbody fusion was performed (PSF or posterior-only spinal fusion).

Our primary research question is: How does LLIF compare to standard fusion approaches (ALIF, TLIF and PSF) in terms of improving segmental lordosis at the operative level(s)? Secondary questions were how LLIF compared to standard approaches in terms of change in operative level(s) disk heights as well as regional lumbar lordosis.

\section{Methods}

This is a retrospective, comparative radiographic analysis among four lumbar fusion approaches (LLIF, ALIF, TLIF and PSF). All lumbar fusion procedures (L1-S1) performed by three fellowship-trained orthopaedic spine surgeons (DWP, EGS and JNS) during a two-year period (January 2008 to December 2009) were reviewed after Institutional Review Board approval. An independent reviewer (SCY) performed the radiographic measurements on digital images using Picture Archiving Communications System (Philips iSite Enterprise) software.

Criteria for exclusion were: severe deformity requiring osteotomies (e.g. pedicle subtraction osteotomy) or extension to the thoracic spine or pelvis; congenital spinal anomalies; procedures to repair pseudarthrosis from a previous fusion procedure; and advanced osseous destruction such as seen in spinal tumors and spondylodiscitis.

\section{Surgical Technique}

The LLIF surgical technique is described in detail in a previously published article. ${ }^{17}$

ALIF procedures were all performed with a vascular co-surgeon. A left-sided retroperitoneal approach was performed in all cases via either a paramedian or a lumbotomy skin incision. At 8 levels, a stand-alone threaded titanium cage (LT cage, Medtronic, Memphis, TN) was inserted. At all other levels, a PEEK cage was used for anterior column support, supplemented by either anterior or posterior fixation.

Two patients underwent single-level minimallyinvasive TLIF via paraspinal muscle-splitting approach. All other TLIF procedures were done in conventional open fashion.

Bilateral facetectomies were performed in 25 patients (33 levels), while 26 patients (32 levels) had unilateral facetectomies (Note: One patient had 2-level TLIF; one unilateral, one bilateral). 
Radiographic Evaluation and Statistical Analysis

Standing pre- and six week post-operative radiographs were evaluated. The following parameters were measured: segmental lordosis at the operative, suprajacent and subjacent levels; regional lumbar lordosis (L1-S1); and anterior and posterior disc heights at the operative level(s) (Figure 1). Segmental lordosis was measured as the angle subtended by lines parallel to the superior endplate of the upper vertebra and inferior endplate of the lower vertebra. All the parameters were recorded in Excel spreadsheet (Microsoft Corporation, Redmond, WA). Measurement changes from pre- to post-operative (segmental lordosis, lumbar lordosis and disc heights) within each group were analyzed using paired t-test $(\alpha=0.05)$. Comparisons of measurement change between groups (LLIF, ALIF, TLIF and PSF) were performed using student's t-test $(\alpha=0.05)$.

\section{Results}

During the study period, 147 patients underwent fusion at 212 levels through the following approaches: LLIF (35 patients; 54 levels); ALIF (36 patients; 57 levels); TLIF (50 patients; 65 levels); and PSF (26 patients; 36 levels). All LLIF procedures were performed at L4-5 level and above. The rest of the fusion approaches were performed at L5-S1 level and above. There were 81 males and 66 females. Average age was 56 years (range $20-84$ ). Table 1 shows the summary of diagnoses for each of the fusion techniques.

Pre- and Postoperative Comparison Within Each Group Mean operative level segmental lordosis change after each procedure is as follows (in decreasing order):

ALIF $3.8 \pm 6.6^{\circ}(\mathrm{p}<0.01) ; \operatorname{LLIF} 3.2 \pm 3.6^{\circ}(\mathrm{p}<0.01)$; TLIF $1.9 \pm 3.9^{\circ}(\mathrm{p}<0.01) ;$ and PSF $0.7 \pm 2.9^{\circ}(\mathrm{p}$ $=0.13)($ Table 2$)$.

Mean operative level anterior disc height change after each procedure is as follows (in decreasing order): ALIF $8.7 \pm 5.3 \mathrm{~mm}(\mathrm{p}<0.01)$; LLIF $5.9 \pm 3.8 \mathrm{~mm}(\mathrm{p}$ $<0.01)$; TLIF $2.8 \pm 3.7 \mathrm{~mm}(\mathrm{p}<0.01)$; and PSF $0.3 \pm$ $1.7 \mathrm{~mm}(\mathrm{p}=0.25)($ Table 3$)$.

Mean operative level posterior disc height change after each procedure is as follows (in decreasing order):
ALIF $3.3 \pm 2.7 \mathrm{~mm}(\mathrm{p}<0.01) ; \mathrm{LLIF} 2.8 \pm 2.5 \mathrm{~mm}(\mathrm{p}$ $<0.01)$; TLIF $1.4 \pm 1.9(\mathrm{p}<0.01)$; and PSF $-0.4 \pm 1.1$ $\mathrm{mm}(\mathrm{p}=0.04)($ Table 3$)$.

Mean suprajacent level segmental lordosis change after each procedure is as follows: ALIF $-2.4 \pm 3.5^{\circ}(\mathrm{p}$ $<0.01)$; LLIF $-0.4 \pm 2.3^{\circ}(\mathrm{p}=0.27) ; \mathrm{TLIF}-0.5 \pm 2.2^{\circ}$ $(\mathrm{p}=0.07)$; and PSF $0.3 \pm 2.6^{\circ}(\mathrm{p}=0.54)($ Table 4$)$.

Mean subjacent level segmental lordosis change after each procedure is as follows: $\mathrm{ALIF}-3.5 \pm 4.9^{\circ}$ ( $\mathrm{p}=$

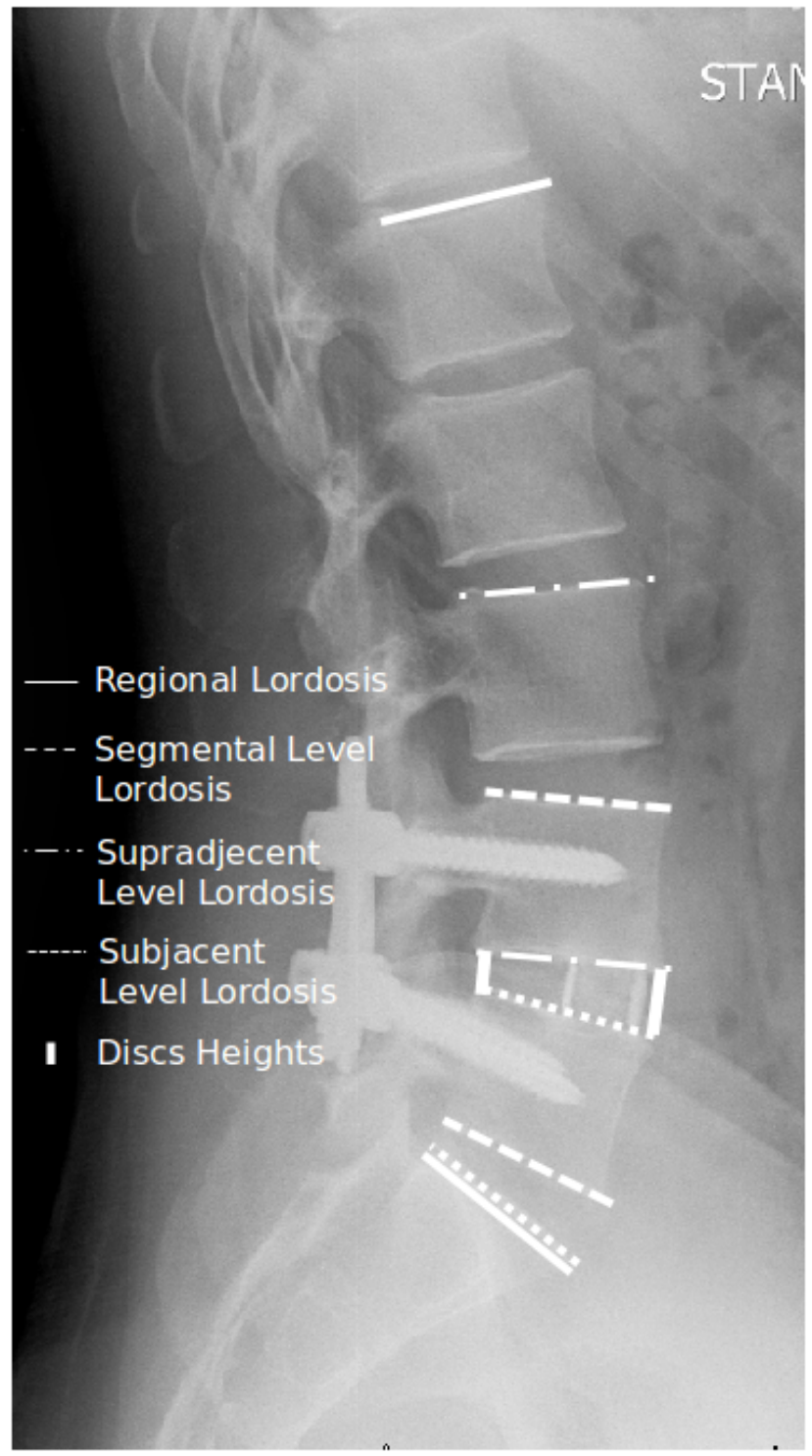

Fig. 1. Lateral standing radiograph of the lumbosacral spine showing measurements of lordosis evaluated in the study. Regional lordosis was measured using the superior endplate of $\mathrm{L} 1$ and S1. Segmental lordosis measurements were measured using the superior endplate of upper vertebra and the inferior endplate of lower vertebra, except at L5-S1 where the superior endplate of S1 was used. 
0.25); LLIF $-0.0 \pm 3.5^{\circ}(\mathrm{p}=0.99) ;$ TLIF $0.0 \pm 2.9^{\circ}$ $(\mathrm{p}=0.99) ;$ and PSF $-0.7 \pm 2.6^{\circ}(\mathrm{p}=0.20)($ Table 4$)$.

Overall lumbar lordosis change after each procedure is as follows: ALIF $4.2 \pm 5.8^{\circ}(\mathrm{p}<0.01)$; LLIF $2.5 \pm$ $4.1^{\circ}(\mathrm{p}<0.01) ;$ TLIF $2.1 \pm 6.0(\mathrm{p}=0.02) ;$ PSF $-0.5 \pm$ $6.2^{\circ}(\mathrm{p}=0.66)($ Table 2$)$.
Subanalysis of regional lordosis change in single and multilevel ( $\geq 2$ levels) fusions was also undertaken (Table 5 and Table 6).

Comparison of Postoperative Change Between Groups Operative level segmental lordosis change comparing the three interbody fusion procedures [ALIF vs LLIF

Table 1. Summary of Diagnoses of the Different Fusion Techniques.

\begin{tabular}{|c|c|c|c|c|c|c|c|}
\hline \multicolumn{2}{|l|}{ LLIF } & \multicolumn{2}{|c|}{ ALIF } & \multicolumn{2}{|c|}{ TLIF } & \multicolumn{2}{|c|}{ PSF } \\
\hline DDD & 17 & DDD & 17 & DDD & 16 & DDD & 5 \\
\hline ASD & 9 & ASD & 4 & ASD & 3 & ASD & 2 \\
\hline Degen Spondylolisthesis & 5 & Degen Spondylolisthesis & 2 & Degen Spondylolisthesis & 15 & Degen Spondylolisthesis & 12 \\
\hline Isthmic Spondylolisthesis & 1 & Isthmic Spondylolisthesis & 10 & Isthmic Spondylolisthesis & 2 & & \\
\hline Spondylosis & 2 & & & Spondylosis & 2 & Spondylosis & 4 \\
\hline Degen Scoliosis & 1 & Degen Scoliosis & 2 & Degen Scoliosis & 3 & Degen Scoliosis & 1 \\
\hline & & Spondylolysis & 1 & HNP (recurrent/far lateral) & 9 & Pars fracture & 2 \\
\hline Total & 35 & Total & 36 & Total & 50 & Total & 26 \\
\hline
\end{tabular}

Table 2. Comparison of preoperative and postoperative lordosis within groups.

\begin{tabular}{|c|c|c|c|c|c|c|}
\hline & \multicolumn{3}{|c|}{ Operative Level } & \multicolumn{3}{|c|}{ Regional (L1-S1) } \\
\hline & $\begin{array}{l}\text { Pre-op } \\
\text { lordosis } \\
\text { (mean } \pm \\
\text { SD) }\end{array}$ & $\begin{array}{r}\text { Post-op } \\
\text { lordosis } \\
\text { (mean } \pm \\
\text { SD) }\end{array}$ & $\begin{array}{r}\mathrm{p} \text { val- } \\
\text { ue }\end{array}$ & $\begin{array}{r}\text { Pre-op } \\
\text { lordosis } \\
\text { (mean } \pm \\
\text { SD) }\end{array}$ & $\begin{array}{r}\text { Post-op } \\
\text { lordosis } \\
\text { (mean } \pm \\
\text { SD) }\end{array}$ & $\begin{array}{r}\text { p val- } \\
\text { ue }\end{array}$ \\
\hline LLIF & $\begin{array}{r}12.1 \pm \\
7.9^{\circ}\end{array}$ & $\begin{array}{r}15.3 \pm \\
8.5^{\circ}\end{array}$ & $\mathrm{p}<0.01$ & $\begin{array}{r}51.5 \pm \\
11.3^{\circ}\end{array}$ & $\begin{array}{r}54.0 \pm \\
10.0^{\circ}\end{array}$ & $\mathrm{p}<0.01$ \\
\hline ALIF & $\begin{array}{r}15.8 \pm \\
11.9^{\circ}\end{array}$ & $\begin{array}{r}19.6 \pm \\
11.7^{\circ}\end{array}$ & $\mathrm{p}<0.01$ & $\begin{array}{r}51.6 \pm \\
13.0^{\circ}\end{array}$ & $\begin{array}{r}55.8 \pm \\
12.6^{\circ}\end{array}$ & $\mathrm{p}<0.01$ \\
\hline TLIF & $\begin{array}{r}13.0 \pm \\
10.3^{\circ}\end{array}$ & $\begin{array}{r}14.9 \pm \\
9.7^{\circ}\end{array}$ & $\mathrm{p}<0.01$ & $\begin{array}{r}47.2 \pm \\
14.2^{\circ}\end{array}$ & $\begin{array}{r}49.3 \pm \\
14.4^{\circ}\end{array}$ & $\mathrm{p}=0.02$ \\
\hline PSF & $\begin{array}{r}14.8 \pm \\
9.6^{\circ}\end{array}$ & $\begin{array}{r}15.5 \pm \\
9.7^{\circ}\end{array}$ & $\mathrm{p}=0.13$ & $\begin{array}{r}49.5 \pm \\
15.0^{\circ}\end{array}$ & $\begin{array}{r}48.9 \pm \\
16.8^{\circ}\end{array}$ & $\mathrm{p}=0.66$ \\
\hline
\end{tabular}

Table 3. Comparison of Preoperative and Postoperative Anterior Disk Height (ADH) and (Posterior Disk Height (PDH) within groups.

\begin{tabular}{|c|c|c|c|c|c|c|}
\hline & $\begin{array}{r}\text { Pre-op } \\
\text { ADH } \\
{[\text { mean }} \\
(\mathrm{mm}) \pm \\
\text { SD] }\end{array}$ & $\begin{array}{r}\text { Post-op } \\
\text { ADH } \\
{[\text { mean }} \\
(\mathrm{mm}) \pm \\
\text { SD] }\end{array}$ & $\begin{array}{r}\text { p val- } \\
\text { ue }\end{array}$ & $\begin{array}{r}\text { Pre-op } \\
\text { PDH } \\
{[\mathrm{mean}} \\
(\mathrm{mm}) \pm \\
\mathrm{SD}]\end{array}$ & $\begin{array}{r}\text { Post-op } \\
\text { PDH } \\
{[\text { mean }} \\
(\mathrm{mm}) \pm \\
\text { SD] }\end{array}$ & $\begin{array}{r}\mathrm{p} \text { val- } \\
\text { ue }\end{array}$ \\
\hline LLIF & $7.9 \pm 4.3$ & $13.8 \pm 3.8$ & $\mathrm{p}<0.01$ & $3.7 \pm 2.5$ & $6.5 \pm 3.1$ & $\mathrm{p}<0.01$ \\
\hline ALIF & $9.7 \pm 5.6$ & $18.4 \pm 5.1$ & $\mathrm{p}<0.01$ & $3.8 \pm 2.0$ & $7.1 \pm 2.6$ & $\mathrm{p}<0.01$ \\
\hline TLIF & $9.8 \pm 5.1$ & $12.6 \pm 3.8$ & $\mathrm{p}<0.01$ & $4.5 \pm 3.0$ & $5.9 \pm 2.9$ & $\mathrm{p}<0.01$ \\
\hline PSF & $9.9 \pm 4.2$ & $10.2 \pm 3.8$ & $\mathrm{p}=0.25$ & $4.3 \pm 2.1$ & $3.9 \pm 2.0$ & $\mathrm{p}=0.04$ \\
\hline
\end{tabular}


$(\mathrm{p}=0.57), \operatorname{ALIF}$ vs TLIF $(\mathrm{p}=0.07)$, and LLIF vs TLIF ( $p=0.11$ ) all failed to show any significant difference. ALIF and LLIF resulted in significantly better operative level lordosis than PSF [ALIF vs PSF $(\mathrm{p}<0.01)$ and LLIF vs PSF $(\mathrm{p}<0.01)]$. No statistically significant difference was seen between TLIF and PSF segmental lordosis change $(\mathrm{p}<0.08)$.

Overall lordosis change comparing the three interbody fusion procedures [ALIF vs LLIF $(\mathrm{p}=0.17)$, $\operatorname{ALIF}$ vs TLIF ( $p=0.12)$, and LLIF vs TLIF ( $\mathrm{p}=$ 0.74 )] did not show any significant difference. Both LLIF and ALIF changes were significantly better than PSF [LLIF vs PSF ( $\mathrm{p}=0.04)$ and ALIF vs PSF $(\mathrm{p}<0.01)]$. TLIF and PSF overall lordosis change were not significantly different $(\mathrm{p}=0.08)$.

Operative level anterior disc height change showed ALIF producing significantly greater change compared to LLIF $(\mathrm{p}<0.01)$, TLIF $(\mathrm{p}<0.01)$ and PSF $(\mathrm{p}<0.01)$; LLIF producing significantly greater change compared to TLIF ( $\mathrm{p}<0.01)$ and PSF ( $\mathrm{p}<$ 0.01 ); and TLIF producing significantly greater change compared to PSF $(\mathrm{p}<0.01)$.

Operative level posterior disc height change showed ALIF and LLIF producing similar improvement ( $\mathrm{p}=$ 0.35). Both were significantly greater than PSF

Table 4. Comparison of Superior (sup) and Inferior (inf) Level lordosis within groups.

\begin{tabular}{|c|c|c|c|c|c|c|}
\hline & Pre-op sup lordosis (mean \pm SD) & Post-op sup lordosis (mean \pm SD) & $\mathrm{p}$ value & Pre-op inf lordosis (mean $\pm \mathrm{SD}$ ) & Post-op inf lordosis (mean \pm SD) & $\mathrm{p}$ value \\
\hline LLIF & $9.1 \pm 8.1^{\circ}$ & $8.7 \pm 7.9^{\circ}$ & $\mathrm{p}=0.27$ & $22.2 \pm 7.3^{\circ}$ & $22.2 \pm 7.7^{\circ}$ & $\mathrm{p}=0.99$ \\
\hline ALIF & $17.3 \pm 10.1^{\circ}$ & $14.8 \pm 9.5^{\circ}$ & $\mathrm{p}<0.01$ & $21.8 \pm 8.5^{\circ}$ & $18.3 \pm 8.2^{\circ}$ & $\mathrm{p}=0.25$ \\
\hline TLIF & $12.6 \pm 10.2^{\circ}$ & $12.1 \pm 10.4^{\circ}$ & $\mathrm{p}=0.07$ & $15.1 \pm 6.3^{\circ}$ & $15.1 \pm 6.0^{\circ}$ & $\mathrm{p}=0.99$ \\
\hline PSF & $11.7 \pm 8.8^{\circ}$ & $12 \pm 9.1^{\circ}$ & $\mathrm{p}=0.54$ & $18.7 \pm 8.1^{\circ}$ & $18.0 \pm 8.1^{\circ}$ & $\mathrm{p}=0.20$ \\
\hline
\end{tabular}

Table 5. Comparison of Regional (L1-S1) Lordosis Change in Single Level

Fusions

\begin{tabular}{|c|c|c|c|c|}
\hline & $\begin{array}{r}\text { Pre-op lordosis } \\
\quad(\text { mean } \pm \text { SD) }\end{array}$ & $\begin{array}{r}\text { Post-op lordosis } \\
\quad(\text { mean } \pm \text { SD })\end{array}$ & $\begin{array}{r}\text { Mean } \\
\text { Change }\end{array}$ & $\begin{array}{r}\mathrm{p} \text { val- } \\
\text { ue }\end{array}$ \\
\hline $\begin{array}{l}\text { LLIF } \\
(\mathrm{n}=18)\end{array}$ & $54.6 \pm 9.2^{\circ}$ & $56.4 \pm 8.0^{\circ}$ & $\begin{array}{r}1.8 \pm \\
3.7^{\circ}\end{array}$ & $\mathrm{p}=0.05$ \\
\hline $\begin{array}{l}\text { ALIF } \\
(\mathrm{n}=23)\end{array}$ & $54.8 \pm 11.3^{\circ}$ & $57.2 \pm 12.7^{\circ}$ & $\begin{array}{r}2.4 \pm \\
5.1^{\circ}\end{array}$ & $\mathrm{p}=0.03$ \\
\hline $\begin{array}{l}\text { TLIF } \\
(\mathrm{n}=38)\end{array}$ & $49.3 \pm 13.2^{\circ}$ & $50.1 \pm 13.6^{\circ}$ & $\begin{array}{r}1.4 \pm \\
4.5^{\circ}\end{array}$ & $\mathrm{p}=0.06$ \\
\hline $\begin{array}{l}\text { PSF } \\
(n=18)\end{array}$ & $50.8 \pm 16.1^{\circ}$ & $51.1 \pm 17.6^{\circ}$ & $\begin{array}{r}0.3 \pm \\
6.9^{\circ}\end{array}$ & $\mathrm{p}=0.86$ \\
\hline
\end{tabular}

Table 6. Comparison of Regional (L1-S1) Lordosis Change in Multilevel ( $\geq 2$ levels) Fusions.

\begin{tabular}{|c|c|c|c|c|}
\hline & $\begin{array}{r}\text { Pre-op lordosis } \\
\quad(\text { mean } \pm \text { SD) }\end{array}$ & $\begin{array}{r}\text { Post-op lordosis } \\
\quad(\text { mean } \pm \text { SD })\end{array}$ & $\begin{array}{r}\text { Mean } \\
\text { Change }\end{array}$ & $\begin{array}{r}\mathrm{p} \mathrm{val}- \\
\mathrm{ue}\end{array}$ \\
\hline $\begin{array}{l}\text { LLIF } \\
(\mathrm{n}=17)\end{array}$ & $48.0 \pm 12.7^{\circ}$ & $51.2 \pm 11.5^{\circ}$ & $\begin{array}{r}3.3 \pm \\
4.5^{\circ}\end{array}$ & $\mathrm{p}=0.01$ \\
\hline $\begin{array}{l}\text { ALIF } \\
(n=13)\end{array}$ & $46.0 \pm 14.3^{\circ}$ & $53.3 \pm 12.6^{\circ}$ & $\begin{array}{r}7.7 \pm \\
5.9^{\circ}\end{array}$ & $\mathrm{p}<0.01$ \\
\hline $\begin{array}{l}\text { TLIF } \\
(\mathrm{n}=12)\end{array}$ & $40.6 \pm 15.9^{\circ}$ & $44.9 \pm 16.7^{\circ}$ & $\begin{array}{r}4.3^{ \pm} \\
9.3^{\circ}\end{array}$ & $\mathrm{p}=0.13$ \\
\hline $\begin{array}{l}\text { PSF } \\
(n=8)\end{array}$ & $46.5 \pm 12.5^{\circ}$ & $44.1 \pm 14.7^{\circ}$ & $\begin{array}{r}-2.4 \pm \\
3.9^{\circ}\end{array}$ & $\mathrm{p}=0.12$ \\
\hline
\end{tabular}


(LLIF $\mathrm{p}<0.01$; ALIF $\mathrm{p}<0.01$ ) and TLIF (LLIF $\mathrm{p}<$ $0.01) ;$ ALIF $\mathrm{p}<0.01)$. TLIF had significantly greater change than PSF $(\mathrm{p}<0.01)$.

\section{Discussion}

Sagittal plane balance and lumbar lordosis correction have become very important goals in spinal fusion surgery, as these have been shown to greatly impact outcomes. ${ }^{1}$ LLIF is a new and promising minimallyinvasive approach to lumbar spine fusion. Our aim in this study was to compare LLIF against other more traditional approaches in terms of operative level lordosis correction and disc height restoration (anterior and posterior), as well as in terms of overall lumbar lordosis change.

Our results show that the operative level lordosis change in all three interbody fusion procedures (LLIF, ALIF and TLIF) produced significantly greater segmental lordosis change compared to PSF. While these results may be intuitive, they serve to highlight the importance of interbody structural support in terms of lordosis restoration.

Our findings in LLIF and ALIF are consistent with a recent study by Watkins, et al. The authors compared the sagittal alignment after LLIF, ALIF and TLIF. They reported mean segmental lordosis improvements of $2.2^{\circ}$ after LLIF and $4.5^{\circ}$ after ALIF, both of which were statistically significant. ${ }^{18} \mathrm{We}$ found improvements of $3.2^{\circ}$ and $3.8^{\circ}$, respectively, both of which were likewise significant. These findings strongly suggest that the LLIF procedure is able to improve lordosis at the operative level, similar to ALIF, even without resection of the anterior longitudinal ligament (ALL).

Previously published case series also show consistent significantly improved segmental sagittal contour with the LLIF procedure (Table 7).

Studies on TLIF performed via unilateral complete facetectomy show no significant improvement in segmental lordosis at the operative level. Watkins et al, in the same study cited above, found an insignificant $0.8^{\circ}$ change after TLIF. ${ }^{18}$ Hsieh et al likewise reported no statistically significant difference in segmental lordosis after TLIF. ${ }^{12}$ They speculated that this might be because of the difficulty in positioning the interbody device in the ideal anterior placement and the presence of a contralateral facet that hinders posterior compression. The importance of positioning the cage as anterior as possible was highlighted by Kida et al. who reported significant improvement of segmental lordosis after cantilever TLIF. ${ }^{21}$

In contrast to the above studies, our results show a statistically significant $1.9^{\circ}$ segmental lordosis improvement after TLIF. This might be explained by the fact that half of the TLIF cases in our series were performed via bilateral facetectomies, although all cases still had only a single cage placed. Separating the results of these two variations of the procedure showed that there is no significant difference in the pre-operative and post-operative lordosis of the unilateral facetectomy group (Table 8). Two studies looking more closely at the effects of bilateral facetectomies in TLIF procedures show significant improvement of surgical level lordosis, consistent with findings in the present study. ${ }^{22,23}$

As with previous studies, our results also show that disc height restoration, both anterior and posterior, is better achieved with interbody cage placement, as LLIF, ALIF and TLIF all yielded significant improvements post-operatively, whereas PSF did not. ${ }^{24-26}$ In fact the post-operative posterior disc height in PSF decreased significantly compared to baseline. Bilateral pedicle screws were used to augment all the PSF procedures. Without structural interbody support, compressive maneuvers may only serve to decrease the posterior disc height of the operative level.

There was significant increase in regional lordosis on the three interbody procedures but none on PSF. This is in contrast to reports of Sharma et al. and Acosta et al on their LLIF cases. ${ }^{14,15}$ Both studies reported a significant increase in segmental lordosis but no change in regional lordosis. Our finding in the LLIF group could probably be explained by the mixed set of single and multilevel fusion in the cohort. When these two subsets are analyzed, we found that patients who underwent multilevel fusion had significantly increased regional lordosis compared to 
baseline. Those with single level LLIF also improved but the increase in lordosis did not quite reach statistical significance.

It is worth noting that among the four procedures only ALIF produced significant change in regional lordosis after a single level operative procedure. This finding may be due to resection of the anterior longitudinal ligament (ALL), which is a routine part of the ALIF procedure, but not of the other procedures. In addition, this approach provides an opportunity to put a tall implant in the ideal anterior location. Anatomic studies have shown that sectioning of the ALL resulted in destabilizing the spinal segment, thus facilitating greater correction as needed. A modification of the LLIF technique known as ACR (anterior column resection) or LIFTAR (lateral interbody fusion with transpsoas ALL release) had been reported as a way to gain larger increases in lordosis with this approach. ${ }^{27,28}$ In our series, purposeful sectioning of the ALL was not performed in any of the LLIF cases.

There are several acknowledged limitations to this study. Foremost is the retrospective nature of the study with its non-randomized nature. Selection of fusion procedure was based solely on the discretion of the treating surgeon, thus introducing the likeli- hood of selection bias. We performed a baseline comparison of pre-operative operative level segmental lordosis measurements, and found no difference between any of the four treatment groups ( $p>0.05$ for all comparisons). The non-standardized method of performing the TLIF procedures, as explained earlier in the Discussion, may also confound comparisons with this group. It is also worth noting that the cases included in this study, although all performed within the same time period, represent an early part in the LLIF learning curve on the part of the authors; it is not known whether additional experience would lead to different findings. Lastly, as the LLIF approach is relatively new, the technique and instrumentation as well as the inventory of available cage shapes and sizes have all evolved since the time period covered by the study.

In conclusion, our study findings show that LLIF, similar to traditional interbody fusion techniques (ALIF and TLIF), is able to improve segmental sagittal lordosis, and is superior to posterior-only fusion in terms of disc height restoration. Although singlelevel procedures are not likely to affect regional lordosis, the LLIF procedure may have a more significant impact on lumbar lordosis when performed at more than one level.

Table 7. Literature on Segmental Lordosis Change after LLIF.

\begin{tabular}{|c|c|c|c|c|c|c|c|c|c|c|}
\hline \multirow[b]{2}{*}{ Studies } & \multicolumn{5}{|c|}{ Segmental Lordosis } & \multicolumn{5}{|c|}{ Regional Lordosis } \\
\hline & $\begin{array}{l}\mathrm{N} \\
\text { (levels) }\end{array}$ & Pre-op & Post-op & Change & $P$ value & $\begin{array}{r}\mathrm{N} \\
\text { (patients) }\end{array}$ & Pre-op & Post-op & Change & $P$ value \\
\hline Sharma, et al. $2011^{15}$ & 87 & $5.4^{\circ}$ & $8.5^{\circ}$ & $3.1^{\circ}$ & $\mathrm{p} \leq 0.001$ & 43 & $47.8 \pm 15.1$ & $48.3 \pm 12.0$ & 0.5 & $\mathrm{p}=0.86$ \\
\hline Acosta, et al. $2011^{14}$ & 66 & $5.3^{\circ}$ & $8.2^{\circ}$ & $2.9^{\circ}$ & $\mathrm{p}<0.0001$ & 36 & 42.1 & $46.2^{\circ}$ & 4.1 & $\mathrm{p}>0.05$ \\
\hline Watkins et al. $2014^{18}$ & 86 & $8.2^{\circ}$ & $10.4^{\circ}$ & $2.2^{\circ}$ & $\mathrm{p}<0.001$ & - & - & - & - & - \\
\hline Tohmeh et al. $2014^{20}$ & 223 & $10.7^{\circ}$ & $13.7^{\circ}$ & $3^{\circ}$ & $\mathrm{p}<0.001$ & - & - & - & - & - \\
\hline Present Study & 54 & $12.1^{\circ}$ & $15.3^{\circ}$ & $3.2^{\circ}$ & $\mathrm{p}<0.0 .1$ & 18 & 51.5 & 54.0 & 2.5 & $\mathrm{P}<0.01$ \\
\hline
\end{tabular}

Table 8.
\begin{tabular}{|l|r|r|r|r|}
\hline $\begin{array}{l}\text { Facetectomies } \\
\text { used in TLIF }\end{array}$ & $\begin{array}{r}\text { Pre-op lordosis } \\
(\text { mean } \pm \text { SD) }\end{array}$ & $\begin{array}{r}\text { Post-op lordosis } \\
(\text { mean } \pm \text { SD) }\end{array}$ & $\begin{array}{r}\text { Mean } \\
\text { Change }\end{array}$ & $\begin{array}{r}\mathrm{p} \text { val- } \\
\text { ue }\end{array}$ \\
\hline Unilateral & $16.1 \pm 10.4^{\circ}$ & $17.1 \pm 9.5^{\circ}$ & $\begin{array}{r}1.0 \pm \\
2.9^{\circ}\end{array}$ & $\mathrm{p}=0.07$ \\
\hline Bilateral & $10.0 \pm 9.5^{\circ}$ & $12.9 \pm 9.6^{\circ}$ & $\begin{array}{r}2.9 \pm \\
4.5^{\circ}\end{array}$ & $\mathrm{p}<0.01$ \\
\hline
\end{tabular}

Downloaded from http://ijssurgery.com/ by guest on April 26, 2023 


\section{References}

1. Glassman SD, Berven S, Bridwell K, Horton W, Dimar JR. Correlation of radiographic parameters and clinical symptoms in adult scoliosis. Spine. Mar 15 2005;30(6):682-688.

2. Lagrone MO, Bradford DS, Moe JH, Lonstein JE, Winter RB, Ogilvie JW. Treatment of symptomatic flatback after spinal fusion. The Journal of bone and joint surgery. American volume. Apr 1988;70(4):569-580.

3. Mac-Thiong JM, Transfeldt EE, Mehbod AA, et al. Can c7 plumbline and gravity line predict health related quality of life in adult scoliosis? Spine. Jul 1 2009;34(15):E519-527.

4. Kuo CS, Hu HT, Lin RM, et al. Biomechanical analysis of the lumbar spine on facet joint force and intradiscal pressure--a finite element study. BMC musculoskeletal disorders. 2010;11:151.

5. Djurasovic MO, Carreon LY, Glassman SD, Dimar JR, 2nd, Puno RM, Johnson JR. Sagittal alignment as a risk factor for adjacent level degeneration: a case-control study. Orthopedics. Jun 2008;31(6):546.

6. Chen WJ, Lai PL, Tai CL, Chen LH, Niu CC. The effect of sagittal alignment on adjacent joint mobility after lumbar instrumentation--a biomechanical study of lumbar vertebrae in a porcine model. Clinical biomechanics. Oct 2004;19(8):763-768.

7. Kumar MN, Baklanov A, Chopin D. Correlation between sagittal plane changes and adjacent segment degeneration following lumbar spine fusion. European spine journal : official publication of the European Spine Society, the European Spinal Deformity Society, and the European Section of the Cervical Spine Research Society. Aug 2001;10(4):314-319. 8. Ozgur BM, Aryan HE, Pimenta L, Taylor WR. Extreme Lateral Interbody Fusion (XLIF): a novel surgical technique for anterior lumbar interbody fusion. The spine journal : official journal of the North American Spine Society. Jul-Aug 2006;6(4):435-443. 9. Villavicencio AT, Burneikiene S, Bulsara KR, Thramann JJ. Perioperative complications in transforaminal lumbar interbody fusion versus anteriorposterior reconstruction for lumbar disc degeneration and instability. Journal of spinal disorders \& techniques. Apr 2006;19(2):92-97.
10. Humphreys SC, Hodges SD, Patwardhan AG, Eck JC, Murphy RB, Covington LA. Comparison of posterior and transforaminal approaches to lumbar interbody fusion. Spine. Mar 1 2001;26(5):567-571. 11. Sasso RC, Best NM, Mummaneni PV, Reilly TM, Hussain SM. Analysis of operative complications in a series of 471 anterior lumbar interbody fusion procedures. Spine. Mar 15 2005;30(6):670-674. 12. Hsieh PC, Koski TR, O'Shaughnessy BA, et al. Anterior lumbar interbody fusion in comparison with transforaminal lumbar interbody fusion: implications for the restoration of foraminal height, local disc angle, lumbar lordosis, and sagittal balance. Journal of neurosurgery. Spine. Oct 2007;7(4):379-386.

13. Jiang SD, Chen JW, Jiang LS. Which procedure is better for lumbar interbody fusion: anterior lumbar interbody fusion or transforaminal lumbar interbody fusion? Arch Orthop Trauma Surg.

Sep;132(9):1259-1266.

14. Acosta FL, Liu J, Slimack N, Moller D, Fessler $\mathrm{R}$, Koski T. Changes in coronal and sagittal plane alignment following minimally invasive direct lateral interbody fusion for the treatment of degenerative lumbar disease in adults: a radiographic study. Journal of neurosurgery. Spine. Jul 2011;15(1):92-96.

15. Sharma AK, Kepler CK, Girardi FP, Cammisa FP, Huang RC, Sama AA. Lateral lumbar interbody fusion: clinical and radiographic outcomes at 1 year: a preliminary report. Journal of spinal disorders \& techniques. Jun 2011;24(4):242-250.

16. Kepler CK, Huang RC, Sharma AK, et al. Factors influencing segmental lumbar lordosis after lateral transpsoas interbody fusion. Orthopaedic surgery. May 2012;4(2):71-75.

17. Yson SC, Sembrano JN, Santos ER, Luna JT, Polly DW, Jr. Does Prone Re-positioning Prior to Posterior Fixation Produce Greater Lordosis in Lateral Lumbar Interbody Fusion (LLIF)? Journal of spinal disorders \& techniques. Jul 132012.

18. Watkins IV RGH, Robert; Watkins III, Robert G. . Sagittal Alignment After Lumbar Interbody Fusion: Comparing Anterior, Lateral, and Transforaminal Approaches. Journal of Spinal Disorders and Techniques. 2013; epub ahead of print.

19. Lee YS, Kim YB, Park SW, Chung C. Comparison of transforaminal lumbar interbody fusion with direct lumbar interbody fusion: clinical and radiologi- 
cal results. Journal of Korean Neurosurgical Society. Dec 2014;56(6):469-474.

20. Tohmeh AG, Khorsand D, Watson B, Zielinski $\mathrm{X}$. Radiographical and clinical evaluation of extreme lateral interbody fusion: effects of cage size and instrumentation type with a minimum of 1-year followup. Spine. Dec 15 2014;39(26):E1582-1591.

21. Kida K, Tadokoro N, Kumon M, Ikeuchi M, Kawazoe T, Tani T. Can cantilever transforaminal lumbar interbody fusion (C-TLIF) maintain segmental lordosis for degenerative spondylolisthesis on a long-term basis? Archives of orthopaedic and trauma surgery. Mar 2014;134(3):311-315.

22. Jagannathan J, Sansur CA, Oskouian RJ, Jr., Fu KM, Shaffrey CI. Radiographic restoration of lumbar alignment after transforaminal lumbar interbody fusion. Neurosurgery. May 2009;64(5):955-963; discussion 963-954.

23. Yson SC, Santos ER, Sembrano JN, Polly DW, Jr. Segmental lumbar sagittal correction after bilateral transforaminal lumbar interbody fusion. Journal of neurosurgery. Spine. Jul 2012;17(1):37-42.

24. Kim JS, Kang BU, Lee SH, et al. Minitransforaminal lumbar interbody fusion versus anterior lumbar interbody fusion augmented by percutaneous pedicle screw fixation: a comparison of surgical outcomes in adult low-grade isthmic spondylolisthesis. Journal of spinal disorders \& techniques. Apr 2009;22(2):114-121.

25. Kim JS, Lee KY, Lee SH, Lee HY. Which lumbar interbody fusion technique is better in terms of level for the treatment of unstable isthmic spondylolisthesis? Journal of neurosurgery. Spine. Feb 2010;12(2):171-177.

26. Kepler CK, Sharma AK, Huang RC, et al. Indi- rect foraminal decompression after lateral transpsoas interbody fusion. Journal of neurosurgery. Spine. Apr 2012;16(4):329-333.

27. Uribe JS, Smith DA, Dakwar E, et al. Lordosis restoration after anterior longitudinal ligament release and placement of lateral hyperlordotic interbody cages during the minimally invasive lateral transpsoas approach: a radiographic study in cadavers. Journal of neurosurgery. Spine. Nov 2012;17(5):476-485.

28. Akbarnia BA, Mundis GM, Jr., Moazzaz P, et al. Anterior column realignment (ACR) for focal kyphotic spinal deformity using a lateral transpsoas approach and ALL release. Journal of spinal disorders \& techniques. Feb 2014;27(1):29-39.

\section{Disclosures}

Jonathan Sembrano has received research support from Nuvasive; Edward Rainier Santos has receeived research support from SI-BONE. Other authors declare no relevant disclosures.

\section{Corresponding Author}

Sharon C. Yson, MD, Department of Orthopaedic Surgery, University of Minnesota, 2450 Riverside Ave S R200, Minneapolis, MN 55454.

scyson@umn.edu

Published 19 May 2015.

This manuscript is generously published free of charge by ISASS, the International Society for the Advancement of Spine Surgery. Copyright @ 2015 ISASS. To see more or order reprints or permissions, see http://ijssurgery.com. 